\title{
SPATIALIZATION OF SOIL RESISTANCE TO PENETRATION FOR LOCALIZED MANAGEMENT BY PRECISION AGRICULTURE TOOLS
}

\author{
Jorge W. Cortez ${ }^{*}$, Victor H. Cavassini ${ }^{2}$, Anamari V. de A. Motomiya ${ }^{2}$, Roberto C. Orlando ${ }^{2}$, \\ Igor Q. M. Valente ${ }^{3}$
}

${ }^{1 *}$ Corresponding author. Universidade Federal da Grande Dourados/ Dourados - MS, Brasil. E-mail: jorge.cortez@ yahoo.com.br

\section{KEYWORDS}

compaction, cone index, decompaction.

\begin{abstract}
Soil resistance to penetration is an indicator of easy measurement which can be used to make scarification / subsoiling recommendations in areas that work with localized management. The objective of this study was to evaluate the spatial variability of soil resistance to penetration (RP) in the area of direct sowing system, and to carry out the recommendation of scarification / subsoiling in a localized way through precision agriculture. The research was conducted in commercial area, in a field of 49.12 ha. The RP collection was with an electronic penetrometer in a sample mesh of 47 points distributed regularly in the area, with georeferenced points. The data were analyzed every $0.10 \mathrm{~m}$ being collected up to $0.40 \mathrm{~m}$ depth, in addition to obtaining the mean and maximum RP values in the profile $(0-0.40 \mathrm{~m})$, and the depth value of the maximum RP in the profile. Soil samples were collected randomly in the area to characterize the water content at the time of RP collection. Data were analyzed using descriptive statistics and geostatistics. The resistance to penetration (RP) presents moderate to strong spatial dependence in the evaluated layers. The RP is in most of the area below the critical limits which demonstrates that there is no need to perform a scarification / subsoiling in the total area, only in a localized way.
\end{abstract}

\section{INTRODUCTION}

The intensive use of the soil for large-scale food production has generated some problems related to its capacity to maintain production. Modern agriculture has evolved into management systems that promote less soil tillage by favoring improved soil structure, water retention, nutrients, and conservation of natural resources. These new concepts promote a new dynamic in agronomic studies with the objective of evaluating its benefits and technological challenges found in this management model (Lin et al., 2014).

Machine traffic and soil management systems can cause changes in its physical structure, increasing density, increasing resistance to penetration, retention of water, aeration, and decrease of total porosity (Carvalho et al., 2012; Montanari et al., 2012; Oliveira et al., 2013).

The resistance to penetration (RP) is widely used as measure for mechanical impedance in the root or drying experience or compacted soils (Whalley et al., 2012) with
RP being related to other attributes that indicate the degree of compaction, such as texture which influences the behavior of soil subjected to external pressures (Stefanoski et al., 2013). The quantification of RP in commercial areas, due to its practicality can be performed with penetrometers. They measure the RP by means of a cone-tipped stem with an angle equal to $30^{\circ}$ simulating the soil resistance to root penetration (Almeida et al., 2012; Whalley et al., 2012; Campos et al., 2013, Lima et al., 2013a).

The compaction identification can be done considering the precision agriculture techniques which takes into account the spatial variability of attributes (Motomiya et al., 2012), and is important to define specific management areas (Alves et al., 2014; Rosalen et al., 2011). The use of these techniques provides better management and understanding of the productive process of agricultural properties (Oliveira et al., 2013; Assumpção et al., 2014).

It is assumed that over time, without soil mobilization, the area reaches critical compaction values in certain locations, generated by the traffic of machines. As

${ }^{2}$ Universidade Federal da Grande Dourados/ Dourados - MS, Brasil.

${ }^{3}$ Universidade Estadual de Campinas/ Campinas - SP, Brasil.

Received in: 7-28-2017

Accepted in: 8-15-2018 
the use of management in total area leads in high cost and a lot of time to execute the operations, the use of sampling strategies and localized management can help in decision making, as it allows to know the spatial variability and to generate maps for localized corrections. In this context, the objective was to evaluate the spatial variability of resistance penetration (RP) of the Distroferric Red Latosol in the layers of $0-0.10 ; 0.10-0.20 ; 0.20-030 ; 0.30-0.40 \mathrm{~m}$, and to generate scarification / subsoiling recommendation maps in an area with direct sowing system.

\section{MATERIAL AND METHODS}

The study was conducted in the year 2016, at Santa Hilda farm in the municipality of Dourados, MS. The place is situated at latitude $22^{\circ} 17^{\prime} \mathrm{S}$, longitude of $54^{\circ} 91^{\prime} \mathrm{W}$ and altitude of $460 \mathrm{~m}$. The climate is type Am, monsoon, with dry winter, average annual rainfall of $1500 \mathrm{~mm}$, and average temperature of $22^{\circ} \mathrm{C}$ (Alvares et al., 2013). The soil of the area is Distroferric Red Latosol (EMBRAPA, 2013), which granulometric data are presented in Table 1.

TABLE 1. Latosol granulometry of Fazenda Santa Hilda, Dourados, MS, 2015.

\begin{tabular}{lccc}
\hline & \multirow{2}{*}{ Attributes } & \multicolumn{2}{c}{ Layers $(\mathrm{m})$} \\
\cline { 2 - 3 } & & $0.00-0.10$ & $0.10-0.20$ \\
\hline Sand $\left(\mathrm{g} \mathrm{kg}^{1}\right)$ & 19.78 & 26.56 \\
Silte $\left(\mathrm{g} \mathrm{kg-}^{1}\right)$ & 29.24 & 37.60 \\
Clay $\left(\mathrm{g} \mathrm{kg-}^{-1}\right)$ & 50.98 & 35.84 \\
\hline
\end{tabular}

The experimental area received conventional soil preparation in 1996 and was then conducted for twenty years on direct sowing system with soybean (summer) and corn (autumn / winter) crops in succession. The field used for scientific research consisted of approximately 49.12 ha.

In the experimental area, using a navigation system

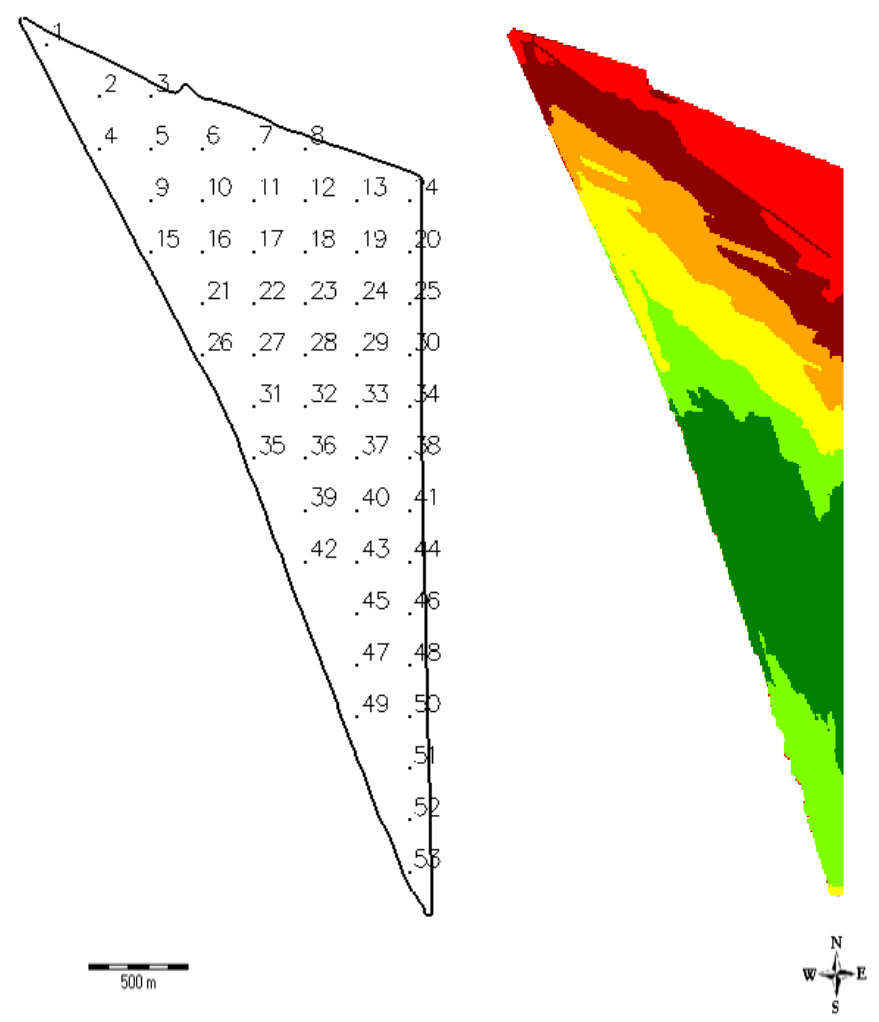

FIGURE 1. Sample mesh and the altitude of the experimental area.

The soil resistance to penetration (RP) was determined by means of an electronic penetrometer (FALKER, 2011), equipped with rod with type 2 cone and $10 \mathrm{~mm}$ collection resolution with a storage capacity of 910 measurements mounted on a quadricycle. model FBX3050 (FALKER, 2013), a sample mesh of approximately one point per hectare was constructed, 47 points (Figure 1) which had their coordinates determined by the navigation system using the WGS84 (World Geodetic System 1984). The navigation system was also used to generate the contour of the area and navigation during the data collection for resistance to penetration (RP).

Altitude (m)

\begin{tabular}{|c|}
\hline Bigger than 446.53 \\
\hline In between 444.27 to 446.53 \\
\hline In between 441.83 to 444.27 \\
\hline In between 439.30 to 441.83 \\
\hline In between 436.71 to 439.30 \\
\hline Smaller than 436.71 \\
\hline
\end{tabular}

The RP data were collected up to the depth of 0.40 $\mathrm{m}$ on October $27^{\text {th }}, 2015$ and evaluated at each $0.10 \mathrm{~m}$ in layers: $0-0.10 ; 0.10-0.20 ; 0.20-0.30 ; 0.30-0.40 \mathrm{~m}$. The samples were taken from the crop line at three replications per point. After measurements we obtained RP average values of the profile, besides the maximum RP value and 
the depth of the maximum RP of the profile, considered as the maps for the soil decompaction, since they indicate the maximum values of the RP and the depth that shows. Thus, the determination of the maximum penetration resistance (RPmax) will serve to describe the maximum RP that the soil offers.

Deformed soil samples were taken in layers 0.0$0.10 ; 0.10-0.20 ; 0.20-0.30$ and $0.30-0.40 \mathrm{~m}$ depth, randomly in the area to determine soil water content after drying in an oven for $24 \mathrm{~h}$ at $105^{\circ} \mathrm{C}$ by the gravimetric method.

The RP data were analyzed through descriptive statistics: mean, median, maximum, minimum, standard deviation, coefficient of variation, asymmetry and kurtosis. The adjustment to the normal distribution was verified by the Ryan-Joiner Test at 5\% probability.

Geostatistics was used to analyze and quantify the existence of spatial dependence of variables, and elaborate semivariograms. The adjustment of the mathematical model for the semivariograms of each variable provided the parameters: Nugget Effect $(\mathrm{C} 0)$, Baseline $(\mathrm{C} 0+\mathrm{C})$ and Range (A) (Vieira et al., 1983). The selection of the models was performed based on the smallest sum of squared residue (SSR) and best coefficient of determination $\left(\mathrm{R}^{2}\right)$. The models are validated by the use of cross validation.

The prediction of RP values for the non-sampled sites was performed by interpolation using the ordinary kriging method, using spatial variability information and semivariogram parameters.

\section{RESULTS AND DISCUSSION}

The values of soil water content (Table 2) were above the friable range, as reported by Bottega et al. (2011) when doing researches in the same area. It can be verified that the water content in the soil may have influenced the $\mathrm{RP}$ readings, but in a homogeneous way in the area. Thus, any change in the RP value of the area is due to the changes in RP behavior caused by the management over the years.

TABLE 2. Soil water content (WC) at the time of penetration resistance sample collect.

\begin{tabular}{ccccc}
\hline Layers $(\mathrm{m})$ & $0.00-0.10$ & $0.10-0.20$ & $0.20-0.30$ & $0.30-0.40$ \\
\hline WC $(\%)$ & 29.00 & 25.80 & 27.01 & 28.56 \\
\hline
\end{tabular}

The critical RP values can be described from 2.0 MPa for the conventional tillage system, minimum tillage should be 3.0 $\mathrm{MPa}$ and 3.5 MPa in direct sowing (Moraes et al., 2014). Thus, the average RP values in the layers are classified as low (Table 3). However, there was large amplitude between the maximum and minimum values in the layers below $0.20 \mathrm{~m}$, which indicates that the area under study needs to be managed differently, since critical points have been detected and may be aggravated in the future, mainly by observing the maximum values and each layer.

TABLE 3. Descriptive statistic for soil resistance to penetration (MPa).

\begin{tabular}{|c|c|c|c|c|c|c|c|}
\hline \multirow[b]{2}{*}{ Parameters } & \multicolumn{4}{|c|}{ Layers (m) } & \multirow[b]{2}{*}{$\begin{array}{l}\text { Profile } \\
\text { average }\end{array}$} & \multirow[b]{2}{*}{ RPMax } & \multirow[b]{2}{*}{$\begin{array}{c}\text { RPMax } \\
\text { Dep. }(\mathrm{cm})\end{array}$} \\
\hline & $0.0-0.1$ & $0.1-0.2$ & $0.2-0.3$ & $0.3-0.4$ & & & \\
\hline Average (MPa) & 0.87 & 2.15 & 2.26 & 1.89 & 1.78 & 2.96 & 20.47 \\
\hline $\mathrm{SD}$ & 0.36 & 0.34 & 0.41 & 0.55 & 0.31 & 0.57 & 4.79 \\
\hline Variance & 131.48 & 119.50 & 170.18 & 302.96 & 0.09 & 327.24 & 23.03 \\
\hline Minimum & 0.33 & 1.38 & 1.61 & 1.35 & 1.20 & 1.94 & 10.33 \\
\hline Maximum & 2.11 & 2.90 & 3.67 & 4.41 & 2.76 & 4.70 & 34.00 \\
\hline CV $(\%)$ & 41.36 & 16.06 & 18.21 & 28.98 & 17.35 & 19.31 & 23.44 \\
\hline As & 1.34 & 0.21 & 1.30 & 2.84 & 1.12 & 1.20 & 0.26 \\
\hline Curtose (k) & 2.10 & 0.19 & 2.67 & 10.53 & 1.68 & 1.69 & 0.82 \\
\hline Normality & $<0.01^{\mathrm{Ns}}$ & $>0.10^{*}$ & $<0.01^{\mathrm{Ns}}$ & $<0.01^{\mathrm{Ns}}$ & $<0.01^{\mathrm{Ns}}$ & $<0.01^{\mathrm{Ns}}$ & $>0.10^{*}$ \\
\hline
\end{tabular}

*: significant distribution, asymmetric data. ${ }^{\text {ss: }}$ non-significant distribution, symmetric data. CV: coefficient of variation. SD: standard deviation. As: Asymmetry. RPMax: resistance to maximum soil penetration; RPMax Dep.: RPMax depth.

A coefficient of variation greater than $35 \%$ reveals that the series is heterogeneous and the average has little meaning; if it is greater than $65 \%$ the series is very heterogeneous and the average has no meaning, but if it is less than $35 \%$ the series is homogeneous and the average has significance and it can be used as a representative of the series from which it was obtained (Nogueira, 2007). Following this classification, only the layer $(0.00-0.10 \mathrm{~m})$ presents a heterogeneous series and the average has little meaning which can be explained by the more superficial layers being those that suffer the most effect of the anthropic action in such a way that higher CVs can be expected. The other layers and other values can be used because their results represent the area in a reliable way.
The observed values of asymmetry and kurtosis suggest that the data do not present normal distribution for the layers $0.0-0.10 \mathrm{~m} ; 0.20-0.30 \mathrm{~m} ; 0.30-0.40 \mathrm{~m}$ and for the mean and maximum RP variables (Table 3 ) in which the higher the correlation, the greater the probability of not rejecting normality (Soares, 2006). The other layers and variables presented significant normal distribution, explained by the mean and median values, agreeing with the values found by Bottega et al. (2011) who evaluated the spatial variability of soil resistance to penetration in a Dystroferric Red Latosol. 
The coefficient of kurtosis $(\mathrm{k})$ is classified as a flat or flattened distribution $(\mathrm{k}>2.63)$ and as leptokurtic or elongated ( $\mathrm{k}<2.63$ ), (Coelho et al., 2012). In this case, except for the layers of 0.20-0.30 m and 0.30-0.40 m (Table $3)$, the others had kurtosis coefficient $\mathrm{k}<2.63$ which classifies them as leptokurtic or elongated, or in other studies, the data present smaller variation and more pronounced modal frequency. When closer to zero, closer to normality and the normal curve, but not required for the application of geostatistics. When normality occurs it tends to facilitate semivariogram adjustment.
The experimental semivariograms were adjusted to the theoretical spherical models for all layers seeking the highest value of the coefficient of determination and the smallest the sum of squared value deviations (Table 4) which corroborated the researches results that indicate this model as the one of higher occurrence for soil attributes (Cruz et al., 2010; Campos et al., 2012; Corado Neto et al., 2015). Coelho et al., (2012) in a Haplic Vertisol in the Northeastern semi-arid region also verified that the spherical model was the one that best fit the RP data in the studied layers.

TABLE 4. Semivariogram data, spatial dependence and cross-validation for soil resistance to penetration in the evaluated layers.

\begin{tabular}{|c|c|c|c|c|c|c|c|}
\hline \multirow[t]{2}{*}{ Parameters } & \multicolumn{4}{|c|}{ Layers (m) } & \multirow[b]{2}{*}{ Average } & \multirow[b]{2}{*}{$\begin{array}{c}\text { RPMax } \\
(\mathrm{MPa})\end{array}$} & \multirow[b]{2}{*}{ RPMax Dep. } \\
\hline & $0-0.1$ & $0.1-0.2$ & $0.2-0.3$ & $0.3-0.4$ & & & \\
\hline & \multicolumn{7}{|c|}{ Semivariogram } \\
\hline Model & Sph. & Sph. & Sph. & Sph. & Sph. & Sph. & Sph. \\
\hline Co & 0.0429 & 0.0523 & 0.0341 & 0.0584 & 0.0193 & 0.0764 & 0.0100 \\
\hline $\mathrm{Co}+\mathrm{C}$ & 0.1658 & 0.1396 & 0.1602 & 0.2938 & 0.0953 & 0.3238 & 26.32 \\
\hline Range & 290.80 & 275.70 & 162.30 & 153.00 & 215.00 & 182.00 & 227.00 \\
\hline \multirow[t]{2}{*}{$\mathrm{R}^{2}$} & 0.99 & 0.77 & 0.46 & 0.74 & 0.93 & 0.91 & 0.92 \\
\hline & \multicolumn{7}{|c|}{ Spatial Dependence Evaluator (SDE) } \\
\hline SDE & 0.74 & 0.62 & 0.79 & 0.80 & 0.80 & 0.76 & 1.00 \\
\hline \multirow[t]{2}{*}{ Class } & Mod & Mod & Strong & Strong & Strong & Strong & Strong \\
\hline & \multicolumn{7}{|c|}{ Cross validation } \\
\hline B & 0.42 & 0.48 & 0.47 & 0.66 & 0.73 & 0.02 & 0.16 \\
\hline Line & M & $\mathrm{M}$ & M & M & M & A & A \\
\hline
\end{tabular}

$\mathrm{Co}=$ nugget effect $\mathrm{Co}+\mathrm{C}=$ baseline $; \mathrm{R}^{2}=$ coefficient of determination; Sph.= Spherical, $\mathrm{SDE}=$ spatial dependence evaluator; Mod: Moderate . B: cross-validation coefficient, A: straight line $(<0.4)$; M: straight line half open; F: closed line $(>0.8)$. RPMax: resistance to maximum soil penetration; RPMax Dep.: RPMax depth.

In the analysis of spatial dependence (SDE) the results indicated moderate to strong values in the layers as proposed by Landim (1998): weak <25\%, moderate between 25 and $75 \%$, and strong $>75 \%$.

The range indicates the boundary distance between points correlated with each other. Collected points greater than the reach is independent, and for their analysis, we can use classical statistics (Vieira, 2000). The ranges in the studied layers ranged from 153 to $290.80 \mathrm{~m}$ in the layers with the greatest reach in the superficial layer (Table 4). In practice, the reach indicates the sample mesh that could be used in the next sampling. It is evident that the used mesh was adequate to capture the variability of the area, since the reach was greater than $100 \mathrm{~m}$.
With the exception of the $0.20-0.30 \mathrm{~m}$ layer, all others presented coefficient of determination $\left(\mathrm{R}^{2}\right)$ above 0.70 (Table 4 ), that is, at least $70 \%$ of the variability in the estimated semivariance values are explained by the adjusted models (Campos et al., 2007; Campos et al., 2012). This was confirmed by the use of cross validation that identified the adjustments of the lines in moderate, except for RPMax and RPMax Dep.

It is verified that in the layer $0.00-0.10 \mathrm{~m}$ the RP was below $2 \mathrm{MPa}$ in most of the area (Figure 2a) which demonstrates no compacting problems in the superficial layer, due to the frequent use of the furrow rod during the sowing of soy and corn that happens every year in the area. 
(a)

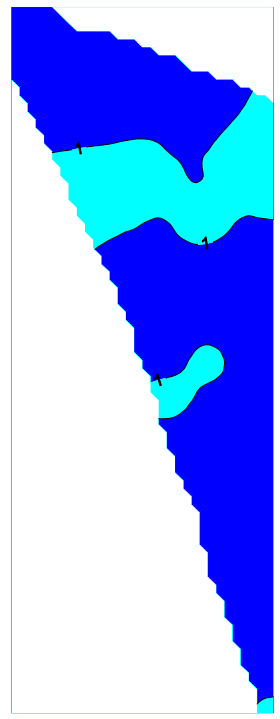

(b)

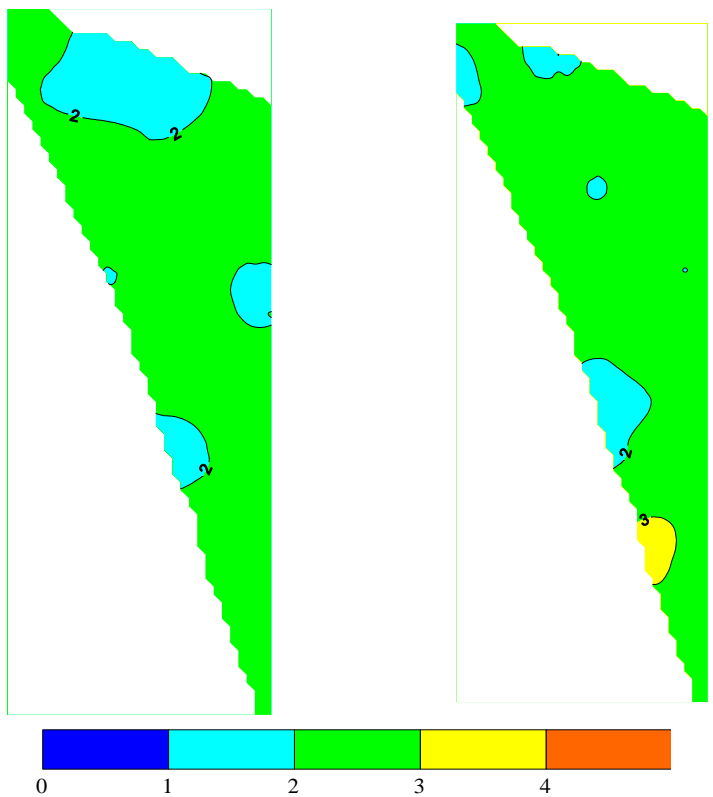

(d)

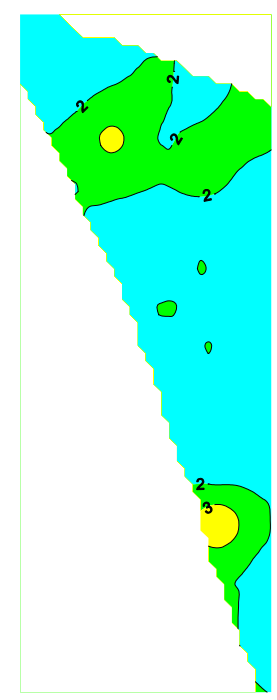

FIGURE 2. Spacialization of soil penetration resistance (MPa) in the evaluated layers: (a) $0.00-0.10 \mathrm{~m}$; (b) 0.10 - $0.20 \mathrm{~m}$; (c) 0.20-0.30 m; (d) 0.30-0.40 m.

The layers $0.10-0.20 \mathrm{~m}$ and $0.20-0.30 \mathrm{~m}$ presented the highest RP values between 2 and $3 \mathrm{MPa}$ and the layer $0.30-0.40 \mathrm{~m}$ showed most part of the area between and 1 and $2 \mathrm{MPa}$ which indicate favorable soil conditions for cultivation in areas with no soil disturbance. Borges et al., (2004) report that the most pronounced increase in RP in deeper layers is due to, among other factors, the pressure of the surface layers on the underlying layers and the pressure exerted by the used machines. According to Lima et al., (2013b) and Vogel \& Fey (2016), the use of agricultural machinery promotes lower porosity and higher soil density, probably because the intense traffic of machines which can result in compaction and consequently greater resistance to penetration. In areas where the direct sowing system (DSS) is applied, it is usually verified that the highest compaction values are found in the intermediate layers (Guedes Filho,
2009). In this research the highest RP values were in the layers $0.10-0.20$ and $0.20-0.30 \mathrm{~m}$, in agreement with the authors mentioned above.

Analyzing the maps of the mean, maximum RP and depth of occurrence of maximum RP (Figure 3), it is verified that the area has low compaction values, smaller than 2.0 MPa with mean profile data (Figure 3a). But when checking the map of the maximum RP (Figure $3 b$ ) part of the area presents values above $3.0 \mathrm{MPa}$ and small portion above 4.0 MPa. Thus, only the portion of the area that is above 4.0 MPa should be decompacted (Moraes et al., 2014). In this range with high RP values the depth of compaction is $0.20-0.40 \mathrm{~m}$. Therefore, in this area, it will be necessary the subsoiling in the minimum depth of $40 \mathrm{~cm}$, since the compacted layer is not a thin line in the soil (Figure 3c). (a) Mean profile

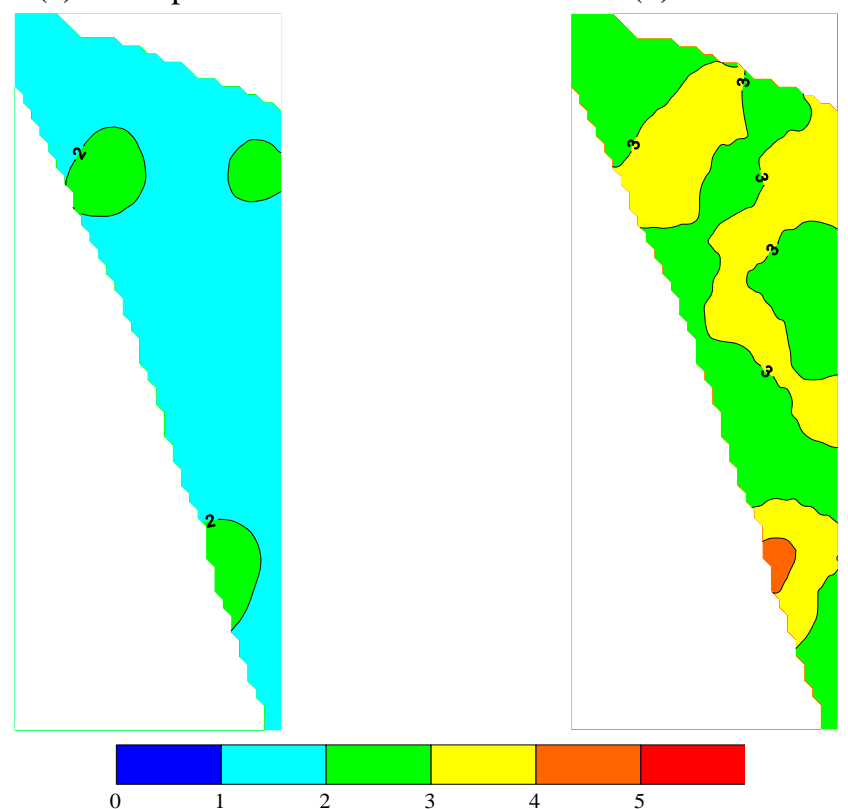

(c) Depth of RPmax (cm)

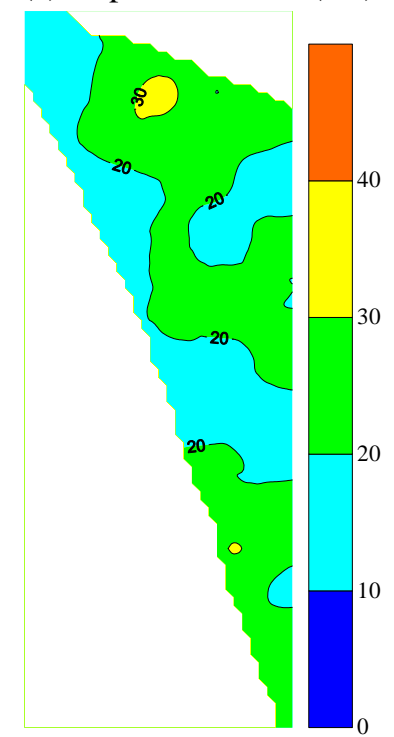

FIGURE 3. Spacialization of the average resistance (MPa) in the profile (a), maximum resistance in the profile (b), and the depth (cm) of the maximum resistance (c). 
The use of the average value of the layer or the soil profile to indicate the need or not to remove compacted layers leads to misunderstandings in the interpretation of the results as it is evident when comparing Figures $3 a$ and $3 b$ that there are differences between the spatialization, being one classified as low RP and the other as medium RP and some points as high RP, respectively. Therefore, it is recommended to use the maximum values to estimate RP in the soils and to predict the maps of the areas where the decompaction is necessary, as well as to predict the depth of scarification / subsoiling.

\section{CONCLUSIONS}

The resistance to penetration (RP) presents moderate to strong spatial dependence in the evaluated layers.

Geostatistical methods allow to define specific regions with higher resistance values to penetration (RP) which enables the appropriate localized management of the area.

The use of spatialization of RP by average means should be avoided, and the recommendation of scarification / subsoiling should be by the maximum RP value of the profile or the soil layer.

The RP is found in most of the area below the critical limits which demonstrates that there is no need to perform a scarification / subsoiling in the total area, only in localized form.

\section{ACKNOWLEDGEMENTS}

We would like to thank the FUNDECT - Fundação de Apoio ao Desenvolvimento do Ensino, Ciência e Tecnologia from the State of Mato Grosso do Sul, by granting the second author a master's scholarship. Also to CAPES - Coordenação de Aperfeiçoamento de Pessoal de Nível Superior by the master's scholarship to the fifth author. To the owners of the Santa Hilda farm, Dourados MS, the Comid Máquinas Ltda and John Deere do Brazil our thanks.

\section{REFERENCES}

Almeida CX, Centurion JF, Jorge RF, Barbosa JC, Andrioli I (2012) Funções de pedotransferência para a curva de resistência do solo à penetração. Revista Brasileira de Ciência do Solo 36(6):1745-1755.

Alvares CA, Stape JL, Sentelhas PC, Gonçalves JLM, Sparovek G (2013) Köppen's climate classification map for Brazil. Meteorologische Zeitschrift 22(6):711-728.

Alves SMF, Queiroz DM, Alcântara GR, Reis EF (2014) Variabilidade espacial de atributos físico-químicos do solo usando técnicas de análise de componentes principais e geoestatística. Bioscience Journal 30(1):22-30.

Assumpção BR, Uribe-Opazo MA, Galea M (2014) Analysis of local influence in geostatistics using Student's t-distribution. Journal of Applied Statistics 41(11): 23232341 .

Borges J R, Pauletto EA, Sousa RO, Pinto LFS, Leitzke VW (2004) Resistência à penetração de um gleissolo submetido a sistemas de cultivo e culturas. Revista Brasileira de Agrociência 10(1):83-86.
Bottega EL, Bottega SP, Silva SA, Queiroz DM, Souza CMA, Rafull LZL (2011) Variabilidade espacial da resistência do solo à penetração em um Latossolo Vermelho distroférrico. Revista Brasileira de Ciências Agrárias 6(2):331-336.

Campos MCC, Ferraz FB, Freitas EVS, Souza ZM (2007) Dependência espacial de atributos físicos e hídricos de um Espodossolo da zona da mata de Pernambuco. Revista de Biologia e Ciências da Terra 7(1):84-91.

Campos MCC, Oliveira IA, Santos LAC, Aquino RE, Soares MRD (2012) Variabilidade espacial da resistência do solo à penetração e umidade em áreas cultivadas com mandioca na região de Humaitá, AM. Revista Agro@mbiente On-line 6(1):9-16.

Campos MC, Aquino RE, Oliveira IA, Bergamim AC (2013) Variabilidade espacial da resistência mecânica do solo à penetração e umidade do solo em área cultivada com cana-de-açúcar na região de Humaitá, Amazonas, Brasil. Revista Brasileira de Ciências Agrárias 8(2):305310.

Carvalho, L A, Meurer I, Silva Junior CA, Centurion JF (2012) Spatial variability of soil physical properties in two management systems in sugarcane crop. Engenharia Agrícola 32(1):60-68.

Coelho DS, Cortez JW, Olszevski N (2012) Variabilidade espacial da resistência mecânica à penetração em Vertissolo cultivado com manga no perímetro irrigado de Mandacaru, Juazeiro, Bahia, Brasil. Revista Brasileira de Ciência do Solo 36(3):755-764.

Corado Neto FC, Sampaio FMT, Veloso MEC, Matias SSR, Andrade FR, Lobato MGR (2015) Variabilidade espacial da resistência à penetração em Neossolo Litólico degradado. Revista Brasileira de Ciência do Solo 39(5):1353-1361.

Cruz JS, Assis Júnior RN, Matias SSR, Camacho-Tamayo JH, Tavares RCastro (2010) Análise espacial de atributos físicos e carbono orgânico em Argissolo VermelhoAmarelo cultivado com cana-de-açúcar. Ciência e Agrotecnologia 34(2):271-278.

EMBRAPA - Empresa Brasileira De Pesquisa Agropecuária (2013) Sistema Brasileiro de Classificação de Solos. Brasília, Embrapa Solos, 353p.

FALKER Automação Agrícola (2011) Sistema automatizado para medição da compactação - Solostar. Florianopólis, Falker, 40p.

FALKER Automação Agrícola (2013) Coletor de dados e navegação em campo - Fieldbox. Florianopólis, Falker, $31 \mathrm{p}$.

Guedes Filho O (2009) Variabilidade espacial e temporal de mapas de colheita e atributos do solo em um sistema de semeadura direta. Dissertação, Instituto Agronômico de Campinas.

Landim PMB (1998) Análise estatística de dados geológicos. São Paulo, Fundação Editora da UNESP, $226 \mathrm{p}$. 
Lima JSS, Silva AS, Silva JM (2013a) Variabilidade espacial de atributos químicos de um Latossolo VermelhoAmarelo cultivado em plantio direto. Revista Ciência Agronômica 44(1):16-23.

Lima IMA, Araújo MC, Barbosa RS (2013b) Avaliação das propriedades físicas do solo em sistemas silvipastoris, região centro-norte, estado do Piauí. Agropecuária Científica do Semiárido 9(1):117-124.

Lin J, Sun Y, Schulze Lammers P (2014) Evaluating model based relationship of cone index, soil water content and bulk density using dual-sensor penetrometer data. Soil And Tillage Research, 138(4):9-16.

Montanari R, Zambianco EC, Corrêa AR, Pellin DMP, Carvalho MP, Dalchiavon FC (2012) Atributos físicos de um Latossolo Vermelho correlacionados linear e espacialmente com a consorciação de guandu com milheto. Revista Ceres 59(1):125-135.

Moraes MT, Debiasi H, Carlesso R, Franchini JC, Silva VR (2014) Critical limits of soil penetration resistance in a Rhodic Eutrudox. Revista Brasileira de Ciência do Solo 38(1):288-298.

Motomiya AVA, Molin JP, Motomiya WR, Baio FHR (2012) Mapeamento do índice de vegetação da diferença normalizada em lavoura de algodão. Pesquisa Agropecuária Tropical 42(1):112-118.

Nogueira MCS (2007) Experimentação agronômica I: conceitos, planejamento e análise estatística. Piracicaba, $479 \mathrm{p}$.
Oliveira IA, Campos MCC, Soares MDR, Aquino RE, Marques Júnior J, Nascimento EP (2013) Variabilidade espacial de atributos físicos em um Cambissolo Háplico sob diferentes usos na região sul do Amazonas. Revista Brasileira de Ciência do Solo 37(4):1103-1112.

Rosalen DL, Rodrigues MS, Chioderoli CA, Brandão FJC, Siqueira DS (2011) Receivers for georeferencing of spatial variability of soil attributes. Engenharia Agrícola 31(6):1162-1169.

Soares AA (2006) O índice de capacidade multivariado como instrumento para avaliação do processo em uma operação de usinagem. Tese, Universidade Federal de Santa Catarina.

Stefanoski DD, Santos GG, Marchão RL, Petter FA, Pacheco LP (2013) Uso e Manejo do solo e seus impactos sobre a qualidade física. Revista Brasileira de Engenharia Agrícola e Ambiental 17(12):1301-1309.

Vieira SR, Hatfield JL, Nielsen DR, Biggar JW (1983) Geoestatiscal the oryand application to variability of some agronomical properties. Hilgardia 51(3):1-75.

Vieira SR (2000) Geoestatística em estudos de variabilidade espacial do solo. In: Novais RF, Alvarez VVH, Schaefer GR eds. Tópicos em ciência do solo. Viçosa, SBCS 1:1-54.

Vogel GF, Fey R (2016) Resistência mecânica à penetração em diferentes sistemas de uso do solo. Revista de Agricultura Neotropical 3(1):21-26.

Whalley WR, Jenkins M, Attenborough K (2012) The velocity of shear waves in unsaturated soil. Soil and Tillage Research 125(9):30-37. 